\title{
NiAl Layered Double Hydroxide/Rice Husk Composite for the Efficient Removal of Malachite Green
}

\author{
Neza Rahayu Palapa ${ }^{1}$, Tarmizi Taher ${ }^{2}$, Normah Normah ${ }^{3}$, and Aldes Lesbani ${ }^{1,3^{*}}$ \\ ${ }^{1}$ Graduate School of Mathematics and Natural Sciences, Faculty of Mathematics and Natural Sciences, Universitas Sriwijaya, \\ Jl. Palembang Prabumulih Km. 32, Ogan Ilir 30662, Indonesia \\ ${ }^{2}$ Department of Environmental Engineering, Faculty of Infrastructure and Regional, Institut Teknologi Sumatera, \\ Jl. Terusan Ryacudu, Way Hui, Lampung Selatan 35365, Indonesia \\ ${ }^{3}$ Research Center of Inorganic Materials and Coordination Complexes, Faculty of Mathematics and Natural Sciences, \\ Universitas Sriwijaya, Jl. Palembang Prabumulih Km. 32, Ogan Ilir 30662, Indonesia
}

\section{*Corresponding author: \\ email:aldeslesbani@pps.unsri.ac.id}

Received: July 28, 2021

Accepted: September 30, 2021

DOI: $10.22146 /$ ijc. 68021

\begin{abstract}
Rice husk biochar (BC) loaded NiAl layered double hydroxide (LDH) has been synthesized to form NiAl $\mathrm{LDH} / \mathrm{BC}$ composite through a co-precipitation method. NiAl $L D H / B C$ has been used as an adsorbent to remove malachite green from water efficiently. The specific surface area analysis revealed that the surface area of NiAl LDH/BC composite increased five times, from 92.6 to $438.9 \mathrm{~m}^{2} / \mathrm{g}$, compared to the original NiAl $L D H$. The adsorption studies revealed that NiAl LDH/BC composite followed the pseudosecond-order kinetic adsorption model while the isotherm followed the Langmuir monolayer adsorption model. The maximum adsorption capacity of NiAl LDH/BC composite prepared with a ratio of 1:1 and 1:0.5 achieved $185.1 \mathrm{mg} / \mathrm{g}$ and $142.9 \mathrm{mg} / \mathrm{g}$, respectively, which is twice higher than the pristine ones (NiAl LDH). The thermodynamic parameters, determined at 303, 313,323, and $333 \mathrm{~K}$, revealed that the adsorption process was spontaneous and endothermic. The NiAl LDH/BC composite was tested for three consecutive adsorption-desorption cycles to investigate its reusability performance. It is found that their adsorption performance slightly decreased to $71.8 \%$ and $68.3 \%$ for NiAl $L D H / B C$ composite 1:0.5 and 1:1, respectively. Therefore, it could be considered that the synthesized NiAl LDH/BC exhibited a good and efficient adsorbent for malachite greed removal.
\end{abstract}

Keywords: NiAl LDH; biochar; adsorption; kinetic study; thermodynamic study; malachite green

\section{- INTRODUCTION}

Synthetic dyes have been widely utilized in many industries such as textile, cosmetics, printing, and paints. It was reported that the annual worldwide production of synthetic dyes had achieved $7 \times 10^{5}$ tons [1]. Unfortunately, around $20 \%$ of dyes used during processing operations are discharged into wastewater [2]. The most provenance of dye wastewater is textile industries, which dispose of up to a hundred thousand tons for a year. The existence of dyes on fresh, natural water has detrimental impacts and is hazardous to the environment and aquatic life because of their mutagenic, allergenic, and carcinogenic effects [3-
4]. Moreover, the presence of metals, chloride and aromatic structure in synthetic dyes further enhances their toxicities [5-6].

Among synthetic dyes, malachite green (MG) is one of the most used dyes in various industrial applications, including dyeing wool, silk, leather, and paper [7-8]. Malachite green is a cationic dye, which belongs to the triphenylmethane category [9]. Many studies have been investigated the hazards of MG for human and mammalians cells. According to Matpang et al. [10], MG in a concentration of less than $1 \mathrm{mg} / \mathrm{L}$ has been reported as toxic to fish, crab, and prawns. 
Therefore, MG was already banned in Europe, the USA, and several countries globally. It is essential to remove MG from industrial wastewater before it is discarded into the aquatic environment due to the detrimental effect on ecological systems and public health [11-12].

The removal of MG from wastewater is difficult because MG's structure is hard to oxidize, low efficiency [13] on nature bio-precipitation and chemistryprecipitation [14]. Several methods have been studied to remove $M G$ from an aqueous solution, such as electrochemical [15], flocculation [16], and adsorption [17]. Other traditional methods include reverse osmosis, electrodialysis, and ion exchange, with limitations such as incomplete removal, high cost, and high energy generation [18]. Among all these methods, adsorption is very effective due to its easy operation, low cost, and efficient removal of pollutants [19-20].

Recently, various adsorbents ranging from organic to inorganic materials have been reported to remove dyes from wastewater such as chitosan [3], zeolite [21], biochar [22], and layered double hydroxide [23-24]. Layered double hydroxide (LDH) is a double dimensional and negative charge inorganic layered material that exhibits brucite structure. Chemical composition of $\mathrm{LDH}$ is given by general formula of $\left.\left[\mathrm{M}^{2+}{ }_{1-\mathrm{x}} \mathrm{M}^{3+}{ }_{\mathrm{x}}(\mathrm{OH})_{2}\right]^{\mathrm{x}+}\left(\mathrm{An}^{-}\right)_{\mathrm{x} / \mathrm{n}}\right]_{\mathrm{n}} \mathrm{H}_{2} \mathrm{O}$; where, composting from bivalent (i.e., $\mathrm{Ni}^{2+}, \mathrm{Fe}^{2+}, \mathrm{Zn}^{2+}$ $\mathrm{Cu}^{2+}$ and $\left.\mathrm{Mg}^{2+}\right)$, trivalent metal ions $\left(\mathrm{Al}^{3+}, \mathrm{Fe}^{3+}\right.$, and $\left.\mathrm{Cr}^{3+}\right)$, and anion in interlayer $\left(\mathrm{Cl}^{-}, \mathrm{SO}_{4}{ }^{2-}, \mathrm{NO}_{3}{ }^{-}\right.$and $\left.\mathrm{CO}_{3}^{-}\right)$[25]. Many researchers have been studying dye removal using LDHs. Shan et al. [26] used MgAl LDH to remove the reactive red dye in an aqueous solution with maximum uptake of $59.49 \mathrm{mg} / \mathrm{g}$. Zhu et al. [27] reported MgAl LDH for adsorption methyl orange in an aqueous solution and obtained adsorption capacity up to $0.453 \mathrm{~mol} / \mathrm{kg}$. Starukh et al. [28] investigated the adsorption ability of $\mathrm{ZnAl} \mathrm{LDH}$ toward methyl orange and obtained that the adsorption process was spontaneous and endothermic, and a possible mechanism for $\mathrm{MO}$ adsorption was proposed. Therefore, due to its excellent properties, $\mathrm{LDH}$ is a promising material to enhance the adsorptive performance of dye with the modification through intercalation [29] and combination to form composite [30].
Recently, Biochar (BC) has been studied as a support agent to increase the surface area of the prepared supported materials [31]. BC, a pyrogenic activated black carbon made from biomass [32], has been widely reported in dyes removal due to its high adsorption capacity and a large surface area [33]. The utilization of BC to improve material characteristics has been widely reported. The modification of $\mathrm{LDH}$ structure using BC can enhance its surface area, stability, adsorption capacity, and regeneration effectivity [34]. The resulting composite is used as an adsorbent to remove contaminants from wastewater by the adsorption method. Meili et al. [35] reported that $\mathrm{MgAl}$ hydrotalcite loaded bone $\mathrm{BC}$ as an adsorbent to remove methylene blue. Wan et al. [36] also reported that $\mathrm{MgFe}$ $\mathrm{LDH}$ composites with bamboo BC were applied as adsorbents to remove organic pollutants such as phosphate from an aqueous solution.

In this work, we investigated NiAl LDH modified with $\mathrm{BC}$ because $\mathrm{Ni}^{2+}$ and $\mathrm{Al}^{3+}$ could form as highly stable LDH with high surface area specific. Based on the literature mentioned earlier, to the best of our knowledge, the development of NiAl LDH loaded rice husk $\mathrm{BC}$ as an adsorbent for MG adsorption is rarely investigated. Furthermore, in this study, NiAl LDH contained different ratios of composite NiAl LDH, and BC was employed to enhance the effectiveness of removing MG in an aqueous system. NiAl LDH loaded rice husk $\mathrm{BC}$ were applied as adsorbent of $\mathrm{MG}$ from an aqueous solution. The effect of various adsorption conditions, including contact time, initial concentration, temperature adsorption, and reusability adsorbent, was investigated in detail. The kinetic and thermodynamic adsorption parameters were also calculated based on a variation of contact time, dye's initial concentration, and temperature adsorption.

\section{- EXPERIMENTAL SECTION}

\section{Materials}

The materials used in the experiment were nickel nitrate trihydrate $\left(\mathrm{Ni}\left(\mathrm{NO}_{3}\right)_{2} \cdot 3 \mathrm{H}_{2} \mathrm{O}, 98 \%\right.$, Merck Darmstadt, Germany), aluminum nitrate nonahydrate 
$\left(\mathrm{Al}\left(\mathrm{NO}_{3}\right)_{3} \cdot 9 \mathrm{H}_{2} \mathrm{O}, 99.9 \%\right.$, Merck Darmstadt, Germany), sodium hydroxide $(\mathrm{NaOH}, 99 \%$, Merck Darmstadt, Germany) and $\mathrm{MG}\left(\mathrm{C}_{23} \mathrm{H}_{25} \mathrm{~N}_{2} \cdot \mathrm{C}_{2} \mathrm{HO}_{4} \cdot 0.5 \mathrm{C}_{2} \mathrm{H}_{2} \mathrm{O}_{4}, 90 \%\right.$, Sigma Aldrich). All those chemicals were purchased from Merck and Sigma Aldrich (purified/p.a. grade) without further purification. The rice husk as the $\mathrm{BC}$ source was obtained from the local rice field.

\section{Instrumentation}

X-ray diffraction pattern of the prepared adsorbent was recorded using XRD Rigaku Miniflex-600 (Japan). The sample was scanned at scan speed $1 \%$ min from the 2theta range $5-70^{\circ}$. The specific surface area was calculated by using the Multipoint BET method based on data collected by ASAP Micromeritics 2020 Accelerated Surface Area and Porosimetry System (USA) at $77 \mathrm{~K}$. Infrared spectra obtained from FTIR Shimadzu Prestige21 (Japan) that measured by $\mathrm{KBr}$ disc method and scanned at wavenumber range of $400-4000 \mathrm{~cm}^{-1}$. The surface morphology of materials was characterized using the SEM Quanta-650 Oxford instrument (Germany). Thermal analysis was conducted using TG-DTA Analyzer Shimadzu DTG-60H (Japan). The concentration of dye was analyzed using UV-Visible spectrophotometer BioBase BK-UV1800 (China) at wavelength $619 \mathrm{~nm}$.

\section{Procedure}

\section{Preparation of $B C$ from rice husk}

$B C$ was produced through thermal treatment of the rice husk; the thermal treatment was carried out in a furnace at $300{ }^{\circ} \mathrm{C}$ under nitrogen flow $\left(10^{\circ} \mathrm{C} / \mathrm{min}\right)$ for 2 h. Thereafter, the reactor was cooled down, and the prepared BC was characterized.

\section{Preparation of NiAI LDH/BC composite}

$\mathrm{NiAl}$ LDH was prepared by co-precipitation method according to Ravuru et al. [37] with slight modification. Meanwhile, NiAl LDH/BC composite preparation is similar to Meili et al. [35] with slight modification. NiAl $\mathrm{LDH} / \mathrm{BC}$ composite was prepared using a coprecipitation method: Nickel nitrate $(10.9 \mathrm{~g} ; 0.750 \mathrm{M})$ and aluminum nitrate $(4.6 \mathrm{~g} ; 0.250 \mathrm{M})$ with ratio molar metal solutions 3:1 were mixed under vigorous stirring for an hour until the complete dissolution of the starting materials. The resulting mixtures were added to a solution of $1 \mathrm{~g}$ and $0.5 \mathrm{~g}$ BC with continuous stirring. The amount of $\mathrm{BC}$ is shown in Table 1. As much as $4 \mathrm{M}$ sodium hydroxide solution was added dropwise until the settlement formed at $\mathrm{pH} 10$. The mixing solution was kept at $80{ }^{\circ} \mathrm{C}$ for $3 \mathrm{~d}$. NiAl LDH/BC composites were washed and dried at $40{ }^{\circ} \mathrm{C}$ for $24 \mathrm{~h}$.

\section{Adsorption study}

The adsorption study was carried out using a batch system. The contact time to determine the kinetics experiments and temperature and concentration on the adsorption process were investigated. The kinetic study was conducted by adding $0.05 \mathrm{~g}$ of adsorbent to $0.05 \mathrm{~L}$ MG solution at room temperature in different initial concentrations. The kinetic parameters were evaluated based on pseudo-first-order (PFO) and pseudo-secondorder (PSO) approaches as reported [38]. A similar procedure investigated the isotherm and thermodynamic study as a kinetic study in various temperatures and initial concentrations. The isotherm models have been investigated in the previous report [39].

\section{Reusability study}

The reusability test was aimed to examine the longevity of NiAl LDH/BC composites after a long period of application. In this study, several reagents such as ethylenediaminetetraacetic acid, sodium chloride, water, sodium hydroxide, hydrochloride acid were used in the desorption process. Reusability evaluation was conducted by adding $0.05 \mathrm{~g}$ of adsorbents to $0.05 \mathrm{~L} \mathrm{MG}$ $100 \mathrm{mg} / \mathrm{L}$. The mixture was shaken for $2 \mathrm{~h}$, followed by filtration to separate the adsorbent from the adsorbate. Then, the adsorbent dried in the oven while the adsorbate had its absorbance read. The dried adsorbent (NiAl LDH/BC-MG LDH) was reused by adding it in $0.025 \mathrm{~L}$ of $\mathrm{HCl}$ followed by stirring for $2 \mathrm{~h}$ and then dried

Table 1. Composites of $\mathrm{BC}$ and $\mathrm{NiAl}$ in NiAl LDH/BC composites

\begin{tabular}{llc}
\hline \multicolumn{1}{c}{ Samples } & $\begin{array}{l}\text { BC } \\
(\mathrm{g}\end{array}$ & $\begin{array}{c}\text { Ni:Al solution }(\mathrm{g} \\
(0.750: 0.250 \mathrm{M}\end{array}$ \\
\hline NiAl LDH/BC composite 1:0.5 & 0.5 & $10.9: 4.6$ \\
NiAl LDH/BC composite 1:1 & 1.0 & $10.9: 4.6$ \\
\hline
\end{tabular}


at room temperature. Finally, the material was used in another adsorption test in a similar procedure, in which this procedure repeated three cycles of operations.

\section{- RESULTS AND DISCUSSION}

Fig. 1(a) shows the IR spectra of NiAl LDH/BC composites that show both $\mathrm{LDH}$ and $\mathrm{BC}$ characteristics. The characteristic band at 3448 and $1635 \mathrm{~cm}^{-1}$ assigned to $\mathrm{OH}$ stretching vibrations and bending vibrations of the hydroxyl groups from water molecules. The band at 1000 $\mathrm{cm}^{-1}$ belongs to the vibration of metal-oxygen, while the bending vibration of nitrate appeared at $1381 \mathrm{~cm}^{-1}$ on LDH pristine and composite materials. The absorption band at $1095 \mathrm{~cm}^{-1}$ denotes the stretching vibration of C$\mathrm{O}$. The intensity of nitrate vibration was decreased after composite formed, and the presence of new vibration at $1095 \mathrm{~cm}^{-1}$ denotes carbon assumed that the successful preparation of the composite materials. Fig. 1(b) shows the diffractogram NiAl LDH/BC composite resembles the characteristic diffraction pattern of $\mathrm{NiAl} \mathrm{LDH}$ and $\mathrm{BC}$, as a similar finding by Palapa et al. [23]. The composite of $\mathrm{NiAl} \mathrm{LDH} / \mathrm{BC}$ composites showed the peaks at $10^{\circ}, 22^{\circ}$, $28^{\circ}, 35^{\circ}$, and $60^{\circ}$ corresponding to reflections of (003), (002), (006), (012), and (110), respectively, which indicated the materials have layer structure and carbon reflection from $\mathrm{BC}$ characteristic [36]. The composite materials showed the characteristic peaks of raw materials (NiAl LDH and BC) with a reduced crystallinity. These phenomena, also supported by the $\mathrm{LDH}(003)$ reflections was shifted to lower 2 theta. The strong reflections of $\mathrm{NiAl}$
LDH observed at a BC content of $0.5 \mathrm{~g}$ were observed at $1 \mathrm{~g}$ with a slight reduction in peak intensities, which indicates that the crystalline structure of the composites slightly deviated with the incorporation of increased BC.

Fig. 2 shows the textural properties of $\mathrm{N}_{2}$ adsorption-desorption, and the results are presented in Table 2. Table 2 shows that the surface area of LDH increased after being supported by $\mathrm{BC}$ along with the decreases in pore size and increased surface area because pores of BC are supported in LDH's surface, decreasing the pore size, thus increasing the surface area. This finding assumed that NiAl LDH occupied the pore of BC with forming NiAl LDH/BC composite, increasing the composites' surface area. The adsorption isotherms of

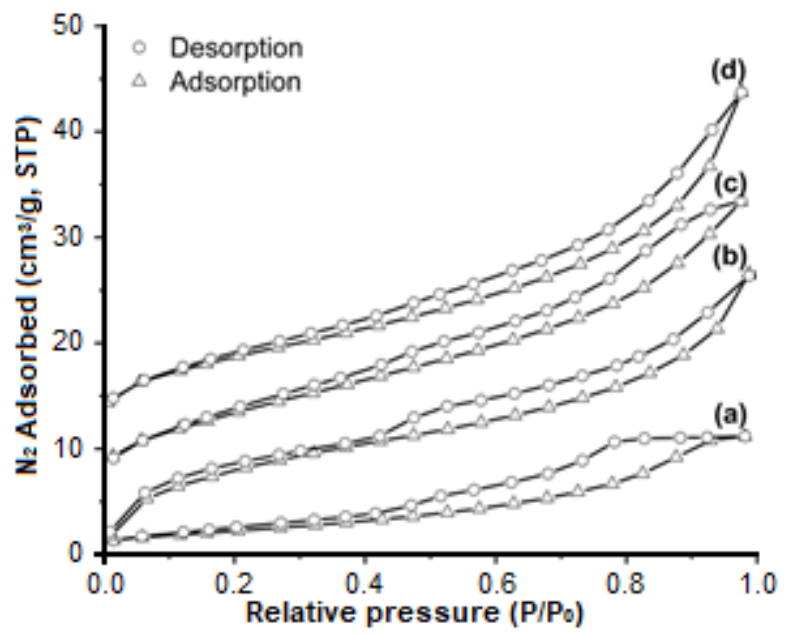

Fig 2. Nitrogen adsorption-desorption curve of materials NiAl LDH (a), BC (b), NiAl LDH/BC composite 1:0.5 (c) and 1:1 (d)
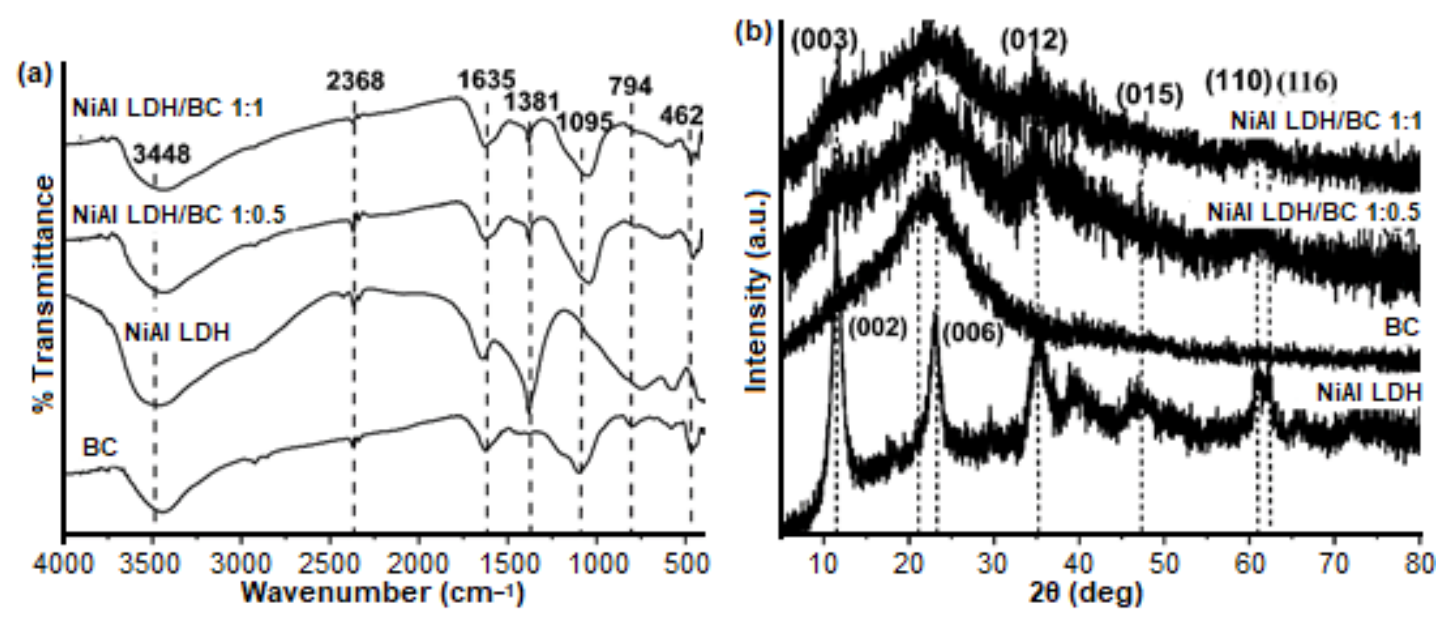

Fig 1. Spectrum FTIR (a) and PXRD pattern (b) 
Table 2. Surface area and pore size of materials

\begin{tabular}{lcc}
\hline Materials & $\begin{array}{c}\text { Surface Area } \\
\left(\mathrm{m}^{2} / \mathrm{g}\right)\end{array}$ & $\begin{array}{c}\text { Pore Size } \\
(\mathrm{nm})\end{array}$ \\
\hline NiAl LDH & 92.6 & 10.2 \\
$\mathrm{BC}$ & 50.9 & 12.0 \\
NiAl LDH/BC composites 1:0.5 & 220.9 & 11.2 \\
NiAl LDH/BC composites 1:1 & 438.9 & 11.3 \\
\hline
\end{tabular}

each material are shown in Fig. 3. The isotherm curve showed the isotherms type IV characteristics of mesoporous materials according to the classification BDDT. The hysteresis of most materials is type $\mathrm{H} 3$ and $\mathrm{H} 4$ for BC. According to IUPAC classification, type $\mathrm{H} 4$ indicated that materials have not well-defined mesoporous structures, whereas the $\mathrm{H} 3$ type implies the presence of slit-shaped pores created by an aggregate particle as mesoporous material characteristic [40].

Fig. 3 exhibits thermogravimetric with divergent thermal analysis (TG-DTA) of the composite materials executed to show the thermal stabilities of materials. As shown in Fig. 3(a), the TG-DTA of NiAl LDH exhibits a two-stage weight loss from water molecules at $80-210^{\circ} \mathrm{C}$ and breaking out of a layered structure of $\mathrm{LDH}$ at around $300{ }^{\circ} \mathrm{C}$. The previous reported also confirm that the endothermic peak at $150-200{ }^{\circ} \mathrm{C}$ indicates the weight loss of water molecule in surface and interlayer [41]. The peak is around $350-560{ }^{\circ} \mathrm{C}$ which show in Fig. $3(\mathrm{~b}-\mathrm{d}$ ). presents the devolatilized and decomposed cellulose and lignin in materials. As similarly reported by James and Rao [42], the stage from $300-600{ }^{\circ} \mathrm{C}$ indicated that the decomposition of cellulose, lignin, and other organic material with strong bonds occurred.

Fig. 3(b) shows two steps of weight loss from BC. The steps included loss of water molecules and evaporation caused that the carbon material was oxidized. According to Mohapatra et al. [43], the BC's DTA showed that the broad and exotherm of the curve
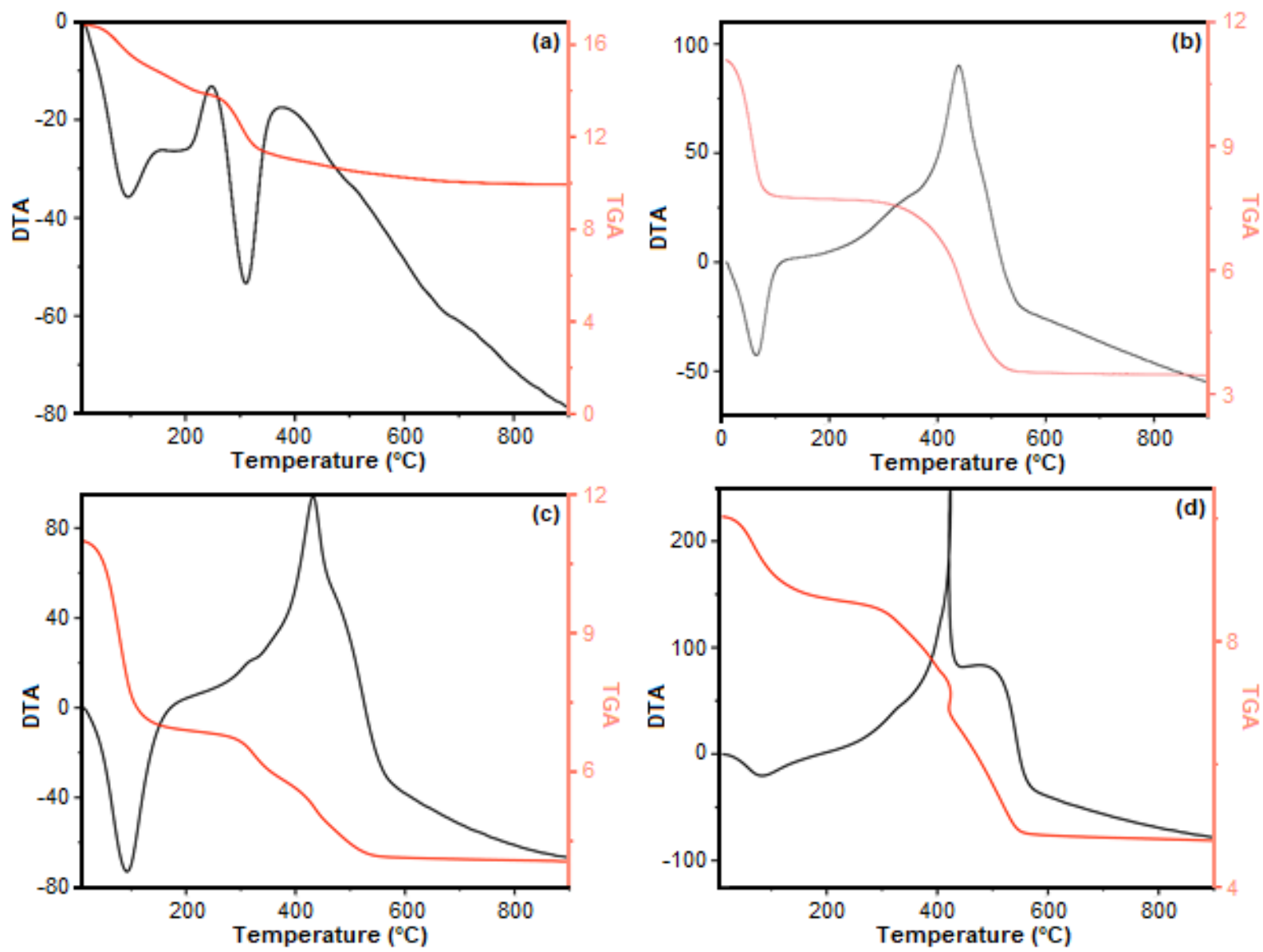

Fig 3. Thermograms of NiAl LDH (a), BC (b), NiAl LDH/BC composites 1:0.5 (c) and 1:1 (d) 
as natural with two peaks, which is the first peaks denotes decay of organic compounds and the second peak is assigned to the decay of cellulose and bonded by organic molecules. Therefore, the $\mathrm{NiAl} \mathrm{LDH} / \mathrm{BC}$ composites have similar weight loss. Fig. 3(c) and 3(d) show the first step is weight loss of water molecules of composite materials, and slight decreases of weight loss from carbon and $\mathrm{LDH}$ interlayer was disappeared.

Fig. 4(a) shows the surface structure of NiAl LDH. The structure of NiAl LDH shows the agglomeration with large particles, which is caused by adjusting $\mathrm{pH}$ and temperature due to the synthesis co-precipitation process [44]. Fig. 4(b) shows the BC structure with large pore materials. This phenom is also confirmed by Table 1, which is the $\mathrm{BC}$ has a larger pore size than $\mathrm{NiAl} \mathrm{LDH}$ and $\mathrm{NiAl}$ LDH/BC composites. Fig. 4(c) shows the NiAl $\mathrm{LDH} / \mathrm{BC}$ composite with a ratio of $1: 1$. The $\mathrm{NiAl} \mathrm{LDH} / \mathrm{BC}$ composites 1:1 shows the agglomeration with predominantly reveals the presence of LDH phase.

The results effect of contact time was calculated by kinetic parameter. Fig. 5 shows the kinetic model fitted using PFO and PSO kinetic models in various contact times. The results showed that the $\mathrm{NiAl} \mathrm{LDH} / \mathrm{BC}$ composites were more adsorbed than NiAl LDH and BC. Furthermore, Fig. 5 presented the equilibrium of $\mathrm{MG}$ reached after $150 \mathrm{~min}$ for $\mathrm{BC}$ and $120 \mathrm{~min}$ for others. The equilibrium MG uptake using NiAl composite 1:0.5 was $79 \mathrm{mg} / \mathrm{L}$, and NiAl composite $1: 1$ was $86 \mathrm{mg} / \mathrm{L}$ from $100 \mathrm{mg} / \mathrm{L}$. The PFO and PSO curve is shown in Fig. 5, and the results of a kinetic parameter are presented in Table 3.

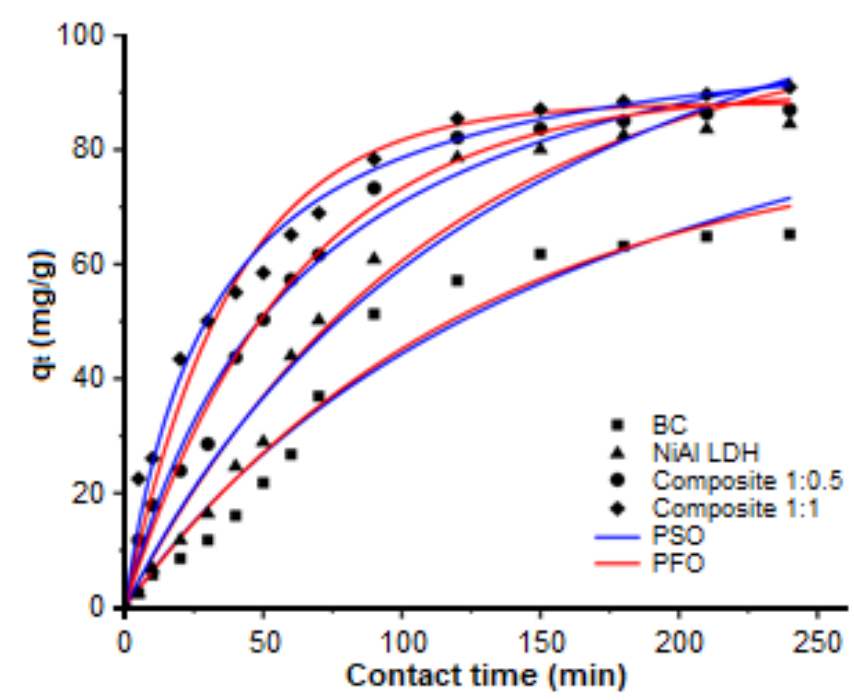

Fig 5. Kinetic curve parameter adsorption of $\mathrm{NiAl} \mathrm{LDH,}$ BC, NiAl LDH/BC composite 1:0.5 and 1:1

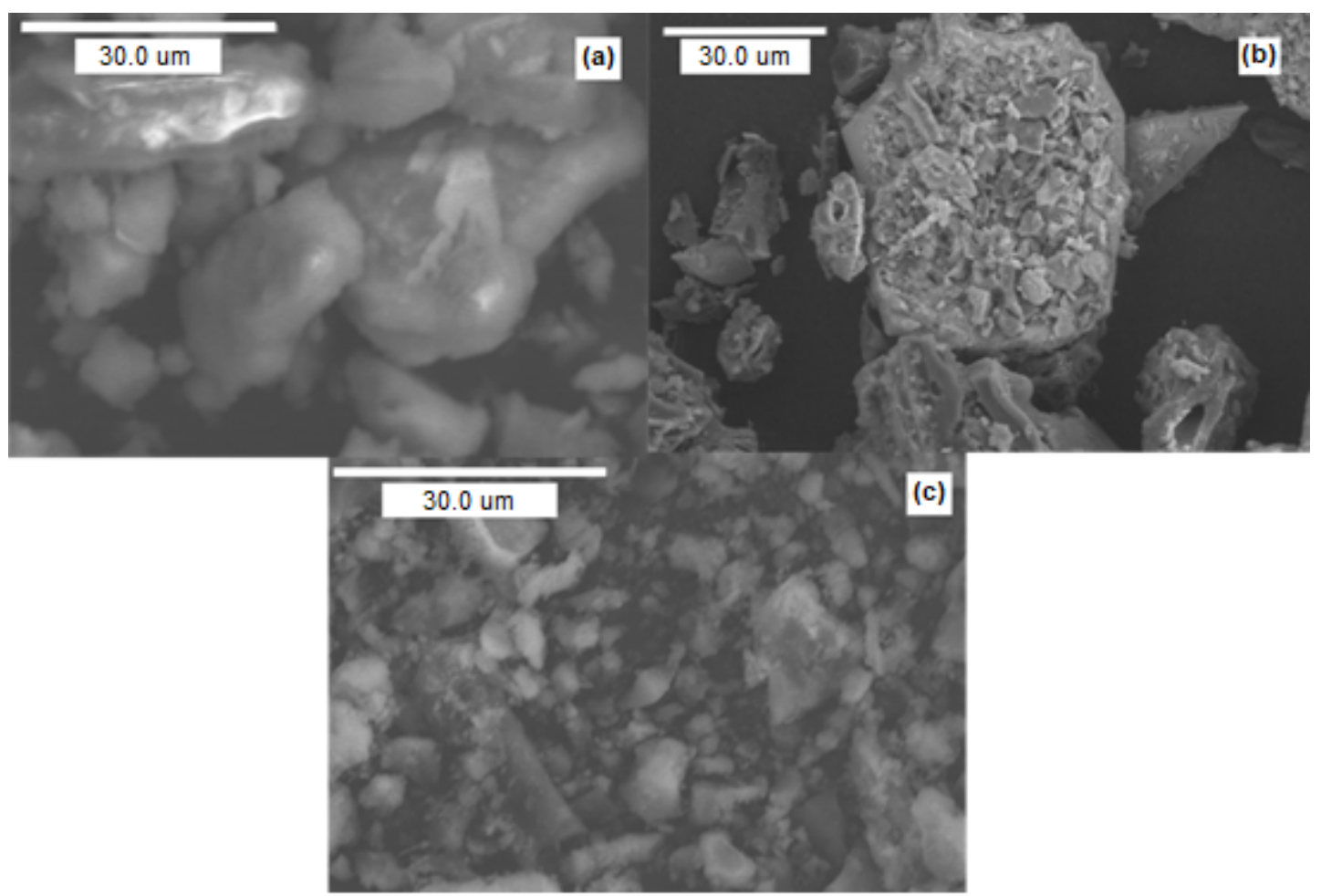

Fig 4. Morphologies of NiAl LDH (a), BC (b), NiAl LDH/BC composite 1:1 (c) 
Table 3. Kinetic parameter adsorption results of materials

\begin{tabular}{lcccccccccc}
\hline \multirow{2}{*}{ Adsorbent } & \multirow{2}{*}{$\mathrm{Qe}_{\exp }$} & \multicolumn{3}{c}{$\mathrm{PFO}$} & \multicolumn{3}{c}{$\mathrm{PSO}$} & \multicolumn{3}{c}{$\mathrm{IPD}$} \\
\cline { 3 - 11 } & & $\mathrm{Qe}_{\text {Calc }}$ & $\mathrm{R}^{2}$ & $\mathrm{Qe}_{\text {Calc }}$ & $\mathrm{R}^{2}$ & $\mathrm{k}_{2}$ & $\mathrm{k}_{1}$ & $\mathrm{k}_{\mathrm{i}}$ & $\mathrm{C}$ & $\mathrm{R}^{2}$ \\
\hline $\mathrm{NiAl} \mathrm{LDH}$ & 42.2 & 60.8 & 0.971 & 60.6 & 0.957 & 0.0001 & 0.022 & 2.964 & 1.677 & 0.913 \\
$\mathrm{BC}$ & 32.6 & 46.2 & 0.908 & 44.2 & 0.962 & 0.0003 & 0.020 & 2.967 & 1.614 & 0.908 \\
$\mathrm{NiAl} \mathrm{LDH/BC} \mathrm{1:0.5}$ & 43.5 & 44.0 & 0.944 & 56.1 & 0.975 & 0.0003 & 0.020 & 3.462 & 1.809 & 0.904 \\
$\mathrm{NiAl} \mathrm{LDH/BC} \mathrm{1:1}$ & 45.4 & 39.5 & 0.992 & 51.2 & 0.995 & 0.0006 & 0.019 & 5.197 & 2.713 & 0.926 \\
\hline
\end{tabular}

Table 3 shows the kinetic parameter of $\mathrm{MG}$ adsorption obtained from the PFO and PSO equation calculation as reported by Lesbani et al. [45] based on experimental data. All materials follow PSO kinetic model based on coefficient correlation $\left(\mathrm{R}^{2}\right)$ which was higher than 0.95 . The value of adsorption capacity of the adsorbent based on the PSO model was also indicated closer to the real experimental value and the graph in Fig. 5. This phenomenon suggested that the adsorption process can be assumed by chemical interaction or chemisorption. A similar phenomenon was also reported by Harizi et al. [46], in which the adsorption kinetics more fitted PSO than PFO indicated the chemisorption mechanism. Furthermore, to identify the importance of diffusion in the adsorption process, mathematical expression of intraparticle diffusion (IPD) model was used $\mathrm{q}_{\mathrm{t}}=\mathrm{k}_{\mathrm{i}} \mathrm{t}^{0.5}+\mathrm{C}$

where $\mathrm{k}_{\mathrm{i}}$ is the IPD constant $\left(\mathrm{mg} / \mathrm{g} \mathrm{min}^{0.5}\right)$ and the intercept $(\mathrm{C})$ reflects the boundary layer effect. The values of $k_{i}$ were calculated from slopes $\left(k_{i}\right)$ of the plots of $q_{t} v s$. $\mathrm{t}^{0.5}$, and the data are presented in Table 3 . The values of $\mathrm{C}$ were higher in NiAl LDH/BC 1:1 revealed more surface adsorption than NiAl LDH, BC and NiAl LDH/BC 1:0.5, these finding reflects the boundary layer effect of the plot. Rates of diffusion were higher in NiAl LDH/BC 1:1, resulting in the high adsorption capacity of $M G$ adsorption. From the results, it can be concluded that all adsorbents followed both surface adsorption and intraparticle diffusion mechanism.

The adsorption isotherm of MG is shown in Fig. 6. The increase of adsorption capacity can be related to the increase in temperature. The isotherm parameters were calculated according to the Langmuir and Freundlich isotherm model formulated by the previous report [47].
Table 4 represents the calculation results of the coefficient correlation, which identifies that Langmuir was the best fitted for NiAl LDH/BC composites. These results exhibited that the surface of adsorbents was uniform, with the mechanism of the adsorption process is a monolayer. The maximum adsorption capacity obtained by NiAl LDH/BC composite 1:1 and 1:0.5 was 185.1 and $142.8 \mathrm{mg} / \mathrm{g}$, respectively, higher than $\mathrm{NiAl}$ LDH $(94.9 \mathrm{mg} / \mathrm{g})$ and BC $(57.0 \mathrm{mg} / \mathrm{g})$. These findings showed that the prepared materials have good properties as adsorbent than other materials for MG removal, as reported by Bagheri et al. [48]. The activated carbon (AC) as adsorbent was prepared from Amygdalus scoparia and was studied to remove MG from an aqueous solution. The adsorption process was obtained a maximum adsorption capacity of $144.3 \mathrm{mg} / \mathrm{g}$ of $\mathrm{MG}$ at $0.01 \mathrm{~g}$ of the adsorbent. Jiang et al. [49] reported ultralight aerogels as MG adsorbent, with an equilibrium adsorption capacity of $53.0 \mathrm{mg} / \mathrm{g}$. Rajabi et al. [49] reported that poly(methyl methacrylate)/graphene oxide- $\mathrm{Fe}_{3} \mathrm{O}_{4}$ (PMMA/GO- $\mathrm{Fe}_{3} \mathrm{O}_{4}$ ) was studied for MG removal with adsorption capacity $11.0 \mathrm{mg} / \mathrm{g}$ at $298 \mathrm{~K}$ after $35 \mathrm{~min}$ adsorption process. Graphene oxide/ $/ \mathrm{Fe}_{3} \mathrm{O}_{4}$ was applied as an adsorbent of MG in an aqueous solution with an adsorption capacity of $179.0 \mathrm{mg} / \mathrm{g}$ [50]. Abukhadra et al. [47] was prepared $\mathrm{Ni} / \mathrm{NiO}$ nanoparticles modified by diatomite skeletons and obtained an experimental equilibrium time of $660 \mathrm{~min}$ with an adsorption capacity of $161 \mathrm{mg} / \mathrm{g}$. CuAl LDH and $\mathrm{CuAl} \mathrm{LDH}$ intercalated using $\mathrm{SiW}_{12} \mathrm{O}_{40}$ Keggin anion was prepared and applied as an MG removal agent. The adsorption process was obtained adsorption capacity $55.8 \mathrm{mg} / \mathrm{g}$ and $149.2 \mathrm{mg} / \mathrm{g}$ for $\mathrm{CuAl} \mathrm{LDH}$ and $\mathrm{CuAl}-$ $\mathrm{SiW}_{12} \mathrm{O}_{40}$, respectively [29]. $\mathrm{CuCr} \mathrm{LDH}$ intercalated 

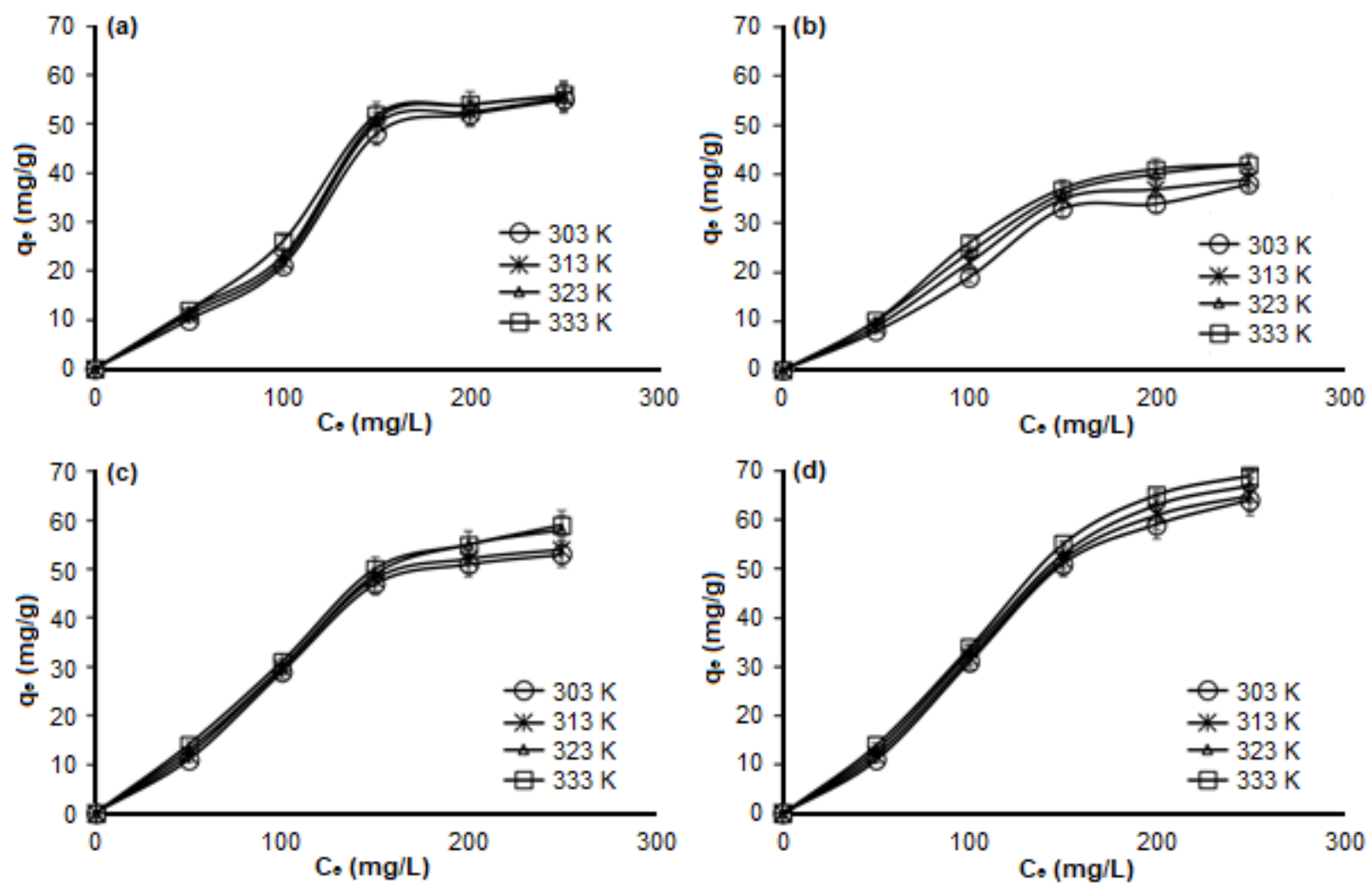

Fig 6. Effect of temperature and initial concentration of MG adsorption using NiAl LDH (a), BC (b), NiAl LDH/BC composites material 1:0.5 (c) and 1:1 (d)

Table 4. Isotherm adsorption parameters of MG adsorption using NiAl, BC, and NiAl LDH/BC composites

\begin{tabular}{|c|c|c|c|c|c|c|}
\hline \multirow{2}{*}{ Adsorbent } & \multirow{2}{*}{$\begin{array}{l}\text { Adsorption } \\
\text { Isotherm }\end{array}$} & \multirow{2}{*}{$\begin{array}{l}\text { Adsorption } \\
\text { Constant }\end{array}$} & \multicolumn{4}{|c|}{$\mathrm{T}(\mathrm{K})$} \\
\hline & & & 303 & 313 & 323 & 333 \\
\hline \multirow[t]{6}{*}{$\mathrm{NiAl}$} & Langmuir & $\mathrm{q}_{\max }$ & 56.2 & 88.3 & 88.2 & 94.9 \\
\hline & & $\mathrm{k}_{\mathrm{L}}$ & 0.005 & 0.011 & 0.036 & 0.366 \\
\hline & & $\mathrm{R}^{2}$ & 0.999 & 0.813 & 0.9459 & 0.975 \\
\hline & Freundlich & $\mathrm{n}$ & 0.5 & 0.6 & 0.7 & 1.1 \\
\hline & & $\mathrm{k}_{\mathrm{F}}$ & 18.523 & 6.806 & 1.587 & 3.807 \\
\hline & & $\mathrm{R}^{2}$ & 0.993 & 0.9731 & 0.975 & 0.9483 \\
\hline \multirow[t]{6}{*}{$\mathrm{BC}$} & Langmuir & $\mathrm{q}_{\max }$ & 44.4 & 52.0 & 53.8 & 57.0 \\
\hline & & $\mathrm{k}_{\mathrm{L}}$ & 0.014 & 0.014 & 0.029 & 0.039 \\
\hline & & $\mathrm{R}^{2}$ & 0.9263 & 0.8962 & 0.8917 & 0.9411 \\
\hline & Freundlich & $\mathrm{n}$ & 0.4 & 0.5 & 0.5 & 0.6 \\
\hline & & $\mathrm{k}_{\mathrm{F}}$ & 38.318 & 22.398 & 5.861 & 2.456 \\
\hline & & $\mathrm{R}^{2}$ & 0.997 & 0.993 & 0.986 & 0.969 \\
\hline \multirow[t]{6}{*}{ NiAl LDH/BC 1:0.5 } & Langmuir & $\mathrm{q}_{\max }$ & 147.0 & 144.9 & 142.8 & 142.8 \\
\hline & & $\mathrm{k}_{\mathrm{L}}$ & 0.073 & 0.108 & 0.163 & 0.249 \\
\hline & & $\mathrm{R}^{2}$ & 0.999 & 0.991 & 0.997 & 0.999 \\
\hline & Freundlich & $\mathrm{n}$ & 14.6 & 15.4 & 16.6 & 3.1 \\
\hline & & $\mathrm{k}_{\mathrm{F}}$ & 91.369 & 96.139 & 101.321 & 46.548 \\
\hline & & $\mathrm{R}^{2}$ & 0.921 & 0.977 & 0.989 & 0.992 \\
\hline
\end{tabular}


Table 4. Isotherm adsorption parameters of MG adsorption using NiAl, BC, and NiAl LDH/BC composites (Continued)

\begin{tabular}{lllcccc}
\hline \multirow{2}{*}{ Adsorbent } & Adsorption & Adsorption & \multicolumn{4}{c}{$\mathrm{T}(\mathrm{K})$} \\
\cline { 4 - 7 } & Isotherm & Constant & 303 & 313 & 323 & 333 \\
\hline NiAl LDH/BC 1:1 & Langmuir & $\mathrm{q}_{\max }$ & 168.9 & 174.9 & 182.9 & 185.1 \\
& & $\mathrm{k}_{\mathrm{L}}$ & 0.011 & 0.031 & 0.049 & 0.067 \\
& & $\mathrm{R}^{2}$ & 0.962 & 0.907 & 0.957 & 0.978 \\
& \multirow{3}{*}{ Freundlich } & $\mathrm{n}$ & 0.5 & 0.6 & 0.8 & 0.9 \\
& & $\mathrm{k}_{\mathrm{F}}$ & 9.883 & 1.112 & 1.286 & 1.969 \\
& & $\mathrm{R}^{2}$ & 0.999 & 0.992 & 0.987 & 0.954 \\
\hline
\end{tabular}

using $\mathrm{SiW}_{12} \mathrm{O}_{40}$, also reported by Palapa et al. [51], was obtained adsorption capacity reached $55.322 \mathrm{mg} / \mathrm{g}$ at 323 $\mathrm{K}$ after $100 \mathrm{~min}$ adsorption time. According to all kinds of literature and compared by Table 4, the obtained $\mathrm{q}_{\max }$ of this research has good performance than others with $\mathrm{q}_{\max }$ of NiAl LDH/BC 1:1 was $185.1 \mathrm{mg} / \mathrm{g}$. These findings showed the efficiency $\mathrm{NiAl} \mathrm{LDH} / \mathrm{BC}$ for the removal of MG dye in aqueous samples.

Table 5 presents the value of the thermodynamic parameters. The $\Delta \mathrm{H}$ and $\Delta \mathrm{S}$ were calculated from the slope and intercept of van't Hoff plots (ln Kd versus $1 / \mathrm{T}$, as shown as Fig. 7). From Fig. 7, the $\Delta \mathrm{H}$ and $\Delta \mathrm{S}$ values were $7.292 \mathrm{~kJ} / \mathrm{mol}$ and $0.024 \mathrm{~J} / \mathrm{K} \mathrm{mol}$, respectively. The positive value of $\Delta S$ of $M G$ adsorption was indicated to the randomness of adsorbent-adsorbate interaction from the adsorption process [52]. The positive value of $\Delta \mathrm{H}$ indicated that the adsorption reaction became endothermic because the MG adsorbed increased with increasing temperature. The negative value of $\Delta G$ at various temperatures denotes the spontaneity adsorption process, and it is more favorable in high temperatures.

Fig. 8 shows the illustration of MG adsorption onto $\mathrm{NiAl} \mathrm{LDH} / \mathrm{BC}$ composite. The adsorption mechanism of adsorption parameter data, i.e., kinetic, isotherm, and thermodynamic data, in the present study, suggested that not only physisorption but also chemisorption can be indicated of MG adsorption onto the adsorbent [53]. In this research, the chemisorption occurs by electrostatic interactions, for example, the interaction of the polar NiAl LDH/BC charged surface with positively charged MG molecule. For supporting phenomena, the increase of the surface area of NiAl LDH/BC indicated that the active sites become more which could contribute to diffuse dye molecules [54]. The large specific surface area and high pore diameter are significant features for the diffusion of dye molecules, increasing $M G$ adsorption [55]. The adsorption interaction between NiAl LDH/BC 1:1 and MG was also confirmed by FTIR

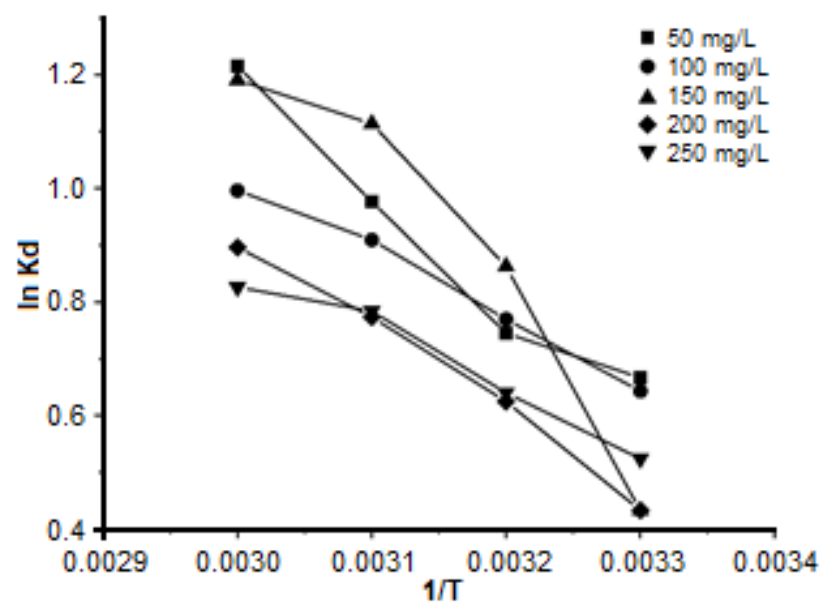

Fig 7. Van't Hoff linearity equation of $M G$ adsorption using NiAl LDH/BC 1:1

Table 5. Thermodynamic study of $\mathrm{MG}$ adsorption onto NiAl, BC and NiAl LDH/BC composites

\begin{tabular}{lclccc}
\hline Adsorbent & $\mathrm{T}(\mathrm{K})$ & $\mathrm{q}_{\mathrm{e}}(\mathrm{mg} / \mathrm{g})$ & $\Delta \mathrm{H}(\mathrm{kJ} / \mathrm{mol})$ & $\Delta \mathrm{S}(\mathrm{J} / \mathrm{K} \mathrm{mol})$ & $\Delta \mathrm{G}(\mathrm{kJ} / \mathrm{mol})$ \\
\hline & 303 & 101.164 & 7.292 & 0.024 & -0.048 \\
NiAl LDH/BC 1:1 & 313 & 106.164 & & & -0.291 \\
& 323 & 110.45 & & & -0.533 \\
& 333 & 114.164 & & & -0.775 \\
\hline
\end{tabular}



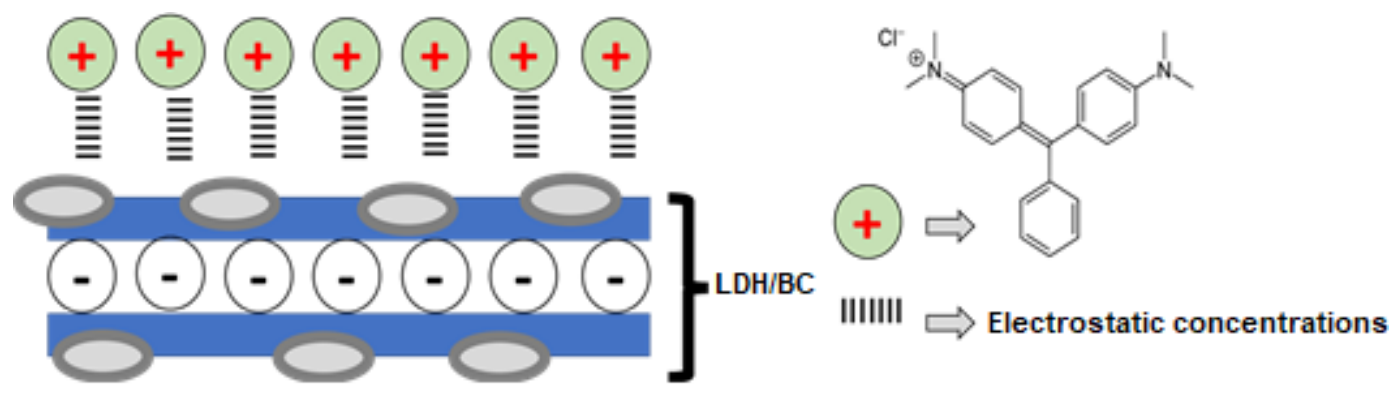

Fig 8. Illustration of $\mathrm{MG}$ adsorption onto $\mathrm{NiAl} \mathrm{LDH} / \mathrm{BC}$ composites

characterization. The FTIR spectrum is a useful tool to identify hydrogen bonding $\left(500-4000 \mathrm{~cm}^{-1}\right)$ of the NiAl $\mathrm{LDH} / \mathrm{BC}$ 1:1 before and after adsorption are shown in Fig. 9. Fig. 9(b), showed exhibited characteristic changes of the hydroxyl groups and nitrate band, which shifted from $3448(\mathrm{OH}), 1635(\mathrm{OH})$, and $1381 \mathrm{~cm}^{-1}(\mathrm{~N}-\mathrm{O})$ before malachite green adsorption to $3289,1660,1560$, and 1388 $\mathrm{cm}^{-1}$ after adsorption, as the evidence for the interaction between $\mathrm{NiAl} \mathrm{LDH} / \mathrm{BC}$ 1:1 and MG. Furthermore, to support the assumption in Fig. 8, the effect of the initial $\mathrm{pH}$ of the solution was determined.

The removal percentage of MG by NiAl LDH/BC 1:1 at different $\mathrm{pH}$ values was then studied (as shown in Fig. 10 ), while keeping the other parameters at constant values $(\mathrm{m}=0.002 \mathrm{~g} ; \mathrm{V}=0.05 \mathrm{~L} ; \mathrm{Co}=50 \mathrm{mg} / \mathrm{L} ; \mathrm{T}=303 \mathrm{~K})$. Results showed that the highest removal efficiency of MG was $48 \%$ observed in the $\mathrm{pH}$ range of 7 . This efficiency decreased to $39 \%$ at $\mathrm{pH}$ ranging 9-10. Meanwhile, the pHpzc of NiAl LDH/BC 1:1 is equal to 5.8. As the initial

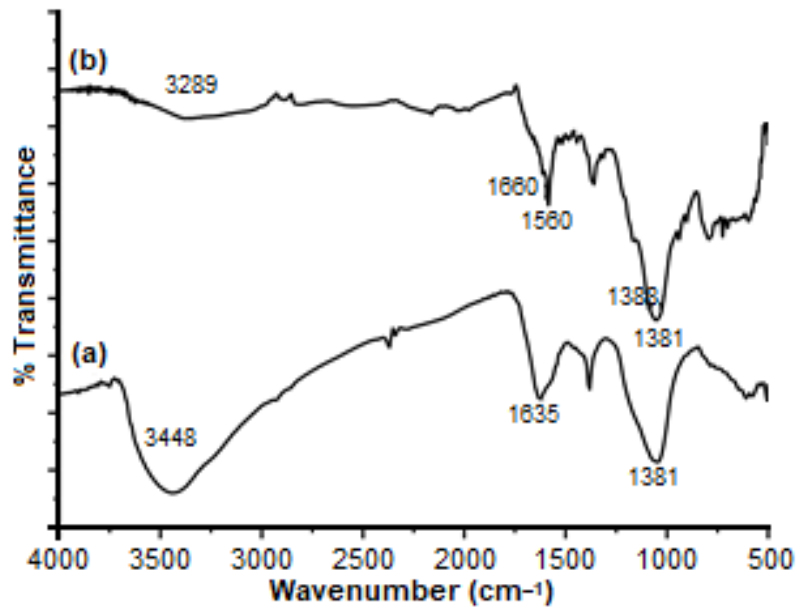

Fig 9. FTIR spectra of NiAl LDH/BC 1:1 before (a) and after (b) adsorption of MG
$\mathrm{pH}$ value of $\mathrm{pH}$ ranging from 3-4 solution decreased, the number of the negatively charged groups at the surface of the adsorbent decreased, while the positively charged groups increased. This behavior does not favor the adsorption due to the presence of electrostatic repulsion. Consequently, the removal percentage of MG increased proportionally to the $\mathrm{pH}$ values, mainly when $\mathrm{pH}>$ pHpzc. Indeed, at $\mathrm{pH}>\mathrm{pHpzc}$, charges at the surface of NiAl LDH/BC 1:1 are mainly negatives, and these charges increase proportionally to the $\mathrm{pH}$. Therefore, the removal efficiency increases when the $\mathrm{pH}$ is in the range of 7-9 due to attractive forces that occur between MG and the negatively charged surface of NiAl LDH/BC 1:1. Therefore, the optimum $\mathrm{pH}$ value that maximizes MG removal from aqueous solution was fixed to 7 .

Fig. 11(a) shows the desorption study by various reagents to obtain the suitable reagent for the desorption process. The desorption process was carried out using organic and inorganic solvents such as diethyl ether, water,

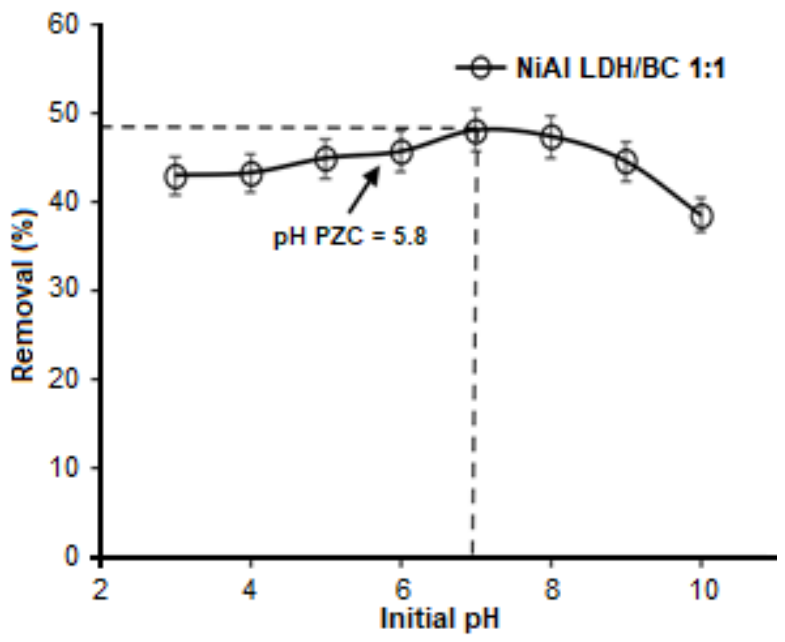

Fig 10. Effect of $\mathrm{pH}$ on $\mathrm{MG}$ adsorption 

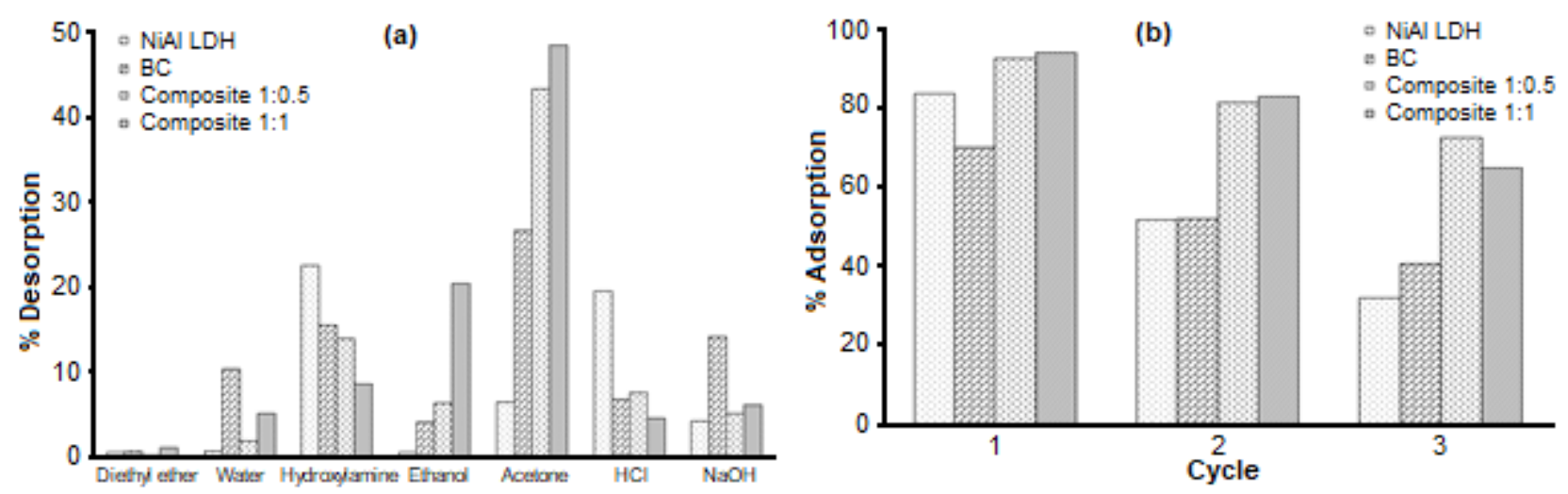

Fig 11. Desorption and reusability study of NiAl, BC, NiAl LDH/BC composite 1:0.5 and 1:1

hydroxylamine, ethanol, acetone, $\mathrm{HCl}$, and $\mathrm{NaOH}$. The higher desorption percentage was achieved by acetone, 48.2\% for $\mathrm{NiAl} \mathrm{LDH/BC} \mathrm{1:1} \mathrm{and} \mathrm{43.8 \%} \mathrm{for} \mathrm{NiAl} \mathrm{LDH/BC}$ 1:0.5. Thus, the desorption process was conducted using acetone as a suitable solvent. According to previous research, the desorption process can be affected by hydrophobicity desorbed, molecule weight, and hydroxyl presence. This finding indicated that MG is more soluble in the organic polar solvent because of forming a hydrogen bond.

Fig. 11(b) shows present the regeneration experiment after three cycles of adsorption-desorption. The efficiency of MG removal was shown to decrease after three cycles slightly. According to Nishimura et al. [56], adsorbents treated in regeneration might damage their structure due to exfoliated included LDH. However, the $\mathrm{NiAl} \mathrm{LDH/BC}$ composites material prepared in this work can be reused, although the adsorption capacity is slightly reduced.

\section{- CONCLUSION}

The NiAl LDH/BC composite has been successfully synthesized, characterized, and applied as an adsorbent to remove MG. The adsorption parameters were determined using kinetic, isotherm, and thermodynamic parameters with various adsorption times, concentrations, and temperatures. MG removal on $\mathrm{NiAl} \mathrm{LDH} / \mathrm{BC}$ composite increased rapidly, and adsorption equilibrium was achieved after 120 min with kinetic parameter follow PSO. The adsorption isotherms could be effectively matched with the Langmuir isotherm model. The maximum adsorption capacity obtained by $\mathrm{NiAl} \mathrm{LDH/BC}$ composite $1: 1$ and $1: 0.5$ was $185.1 \mathrm{mg} / \mathrm{g}$ and $142.8 \mathrm{mg} / \mathrm{g}$, respectively, higher than $\mathrm{NiAl} \mathrm{LDH}(94.9 \mathrm{mg} / \mathrm{g})$ and $\mathrm{BC}$ $(57.0 \mathrm{mg} / \mathrm{g})$. The thermodynamic analysis indicates the spontaneous adsorption process, endothermic and the randomness of adsorbent-adsorbate interaction. Furthermore, NiAl LDH/BC composites exhibited good recycling performance. Finally, the utilization of the NiAl LDH/BC composite shows the material is a potential material as a removal agent.

\section{- ACKNOWLEDGMENTS}

The authors would like to thank the Research Centre of Inorganic Materials and Complexes Universitas Sriwijaya for supporting instrumentation and analysis.

\section{- AUTHOR CONTRIBUTIONS}

$\mathrm{NRP}$ and $\mathrm{N}$ experimented, collecting and assembling the data, AL wrote the manuscript and planning the research, TT and NRP analysis and interpretation the data. All authors agreed to the final version of this manuscript.

\section{- REFERENCES}

[1] Srivastava, S., Sinha, R., and Roy, D., 2004, Toxicological effects of malachite green, Aquat. Toxicol., 66 (3), 319-329.

[2] Bielska, M., Sobczyńska, A., and Prochaska, K., 2009, Dye-surfactant interaction in aqueous solutions, Dyes Pigm., 80 (2), 201-205.

[3] Bekçi, Z., Özveri, C., Seki, Y., and Yurdakoç, K., 2008, Sorption of malachite green on chitosan bead, J. Hazard. Mater., 154 (1-3), 254-261. 
[4] Weber, E.J., and Adams, R.L., 1995, Chemical- and sediment-mediated reduction of the azo dye Disperse Blue 79, Environ. Sci. Technol., 29 (5), 1163-1170.

[5] Ratna, and Padhi, B.S., 2012, Pollution due to synthetic dyes toxicity \& carcinogenicity studies and remediation, Int. J. Environ. Sci., 3 (3), 940-955.

[6] Panswad, T., and Luangdilok, W., 2000, Decolorization of reactive dyes with different molecular structures under different environmental conditions, Water Res., 34 (17), 4177-4184.

[7] Siregar, P.M.S.B.N., Palapa, N.R., Wijaya, A., Fitri, E.S., and Lesbani, A., 2021, Structural stability of $\mathrm{Ni} / \mathrm{Al}$ layered double hydroxide supported on graphite and biochar toward adsorption of Congo red, Sci. Technol. Indones., 6 (2), 85-95.

[8] Boutemak, K., Taoualit, N., Cheknane, B., Laslouni, O., Djeddou, S., Medaoud, K., Mazouni, I., and Aoudj, S., 2019, Equilibrium, kinetic and thermodynamic study of green malachite and rhodamine-B dyes sorption on olive pomace, Chem. Eng. Trans., 73, 277-282.

[9] Esan, O.S., Kolawole, A.O., and Olumuyiwa, A.C., 2019, The removal of single and binary basic dyes from synthetic wastewater using bentonite clay adsorbent, Am. J. Polym. Sci. Technol., 5 (1), 16-28.

[10] Matpang, P., Sriuttha, M., and Piwpuan, N., 2017, Effects of malachite green on growth and tissue accumulation in pak choy (Brassica chinensis Tsen \& Lee ), Agric. Nat. Resour., 51 (2), 96-102.

[11] Li, J., Fan, Q., Wu, Y., Wang, X., Chen, C., Tang, Z., and Wang, X., 2016, Magnetic polydopamine decorated with $\mathrm{Mg}$-Al LDH nanoflakes as a novel bio-based adsorbent for simultaneous removal of potentially toxic metals and anionic dyes, J. Mater. Chem. A, 4 (5), 1737-1746.

[12] Oldring, P.K.T., and Nehring, U., 2007, Packing Materials - 7. Metal Packing for Foodstuffs, ILSI Europe Report Series, ILSI Europe Packaging Materials Task Force, Washington, DC, US.

[13] Krishna Murthy, T.P., Gowrishankar, B.S., Chandra Prabha, M.N., Kruthi, M., and Hari Krishna, R., 2019, Studies on batch adsorptive removal of malachite green from synthetic wastewater using acid treated coffee husk: Equilibrium, kinetics and thermodynamic studies, Microchem. J., 146 192201.

[14] Qu, W., Yuan, T., Yin, G., Xu, S., Zhang, Q., and Su, H., 2019, Effect of properties of activated carbon on malachite green adsorption, Fuel, 249, 45-53.

[15] Nidheesh, P.V., Zhou, M., and Oturan, M.A., 2018, An overview on the removal of synthetic dyes from water by electrochemical advanced oxidation processes, Chemosphere, 197, 210-227.

[16] Shankar, Y.S., Ankur, K., Bhushan, P., and Mohan, D., 2019, "Utilization of Water Treatment Plant (WTP) Sludge for Pretreatment of Dye Wastewater Using Coagulation/Flocculation" in Advances in Waste Management, Eds. Kalamdhad, A., Singh, J., and Dhamodharan, K., Springer Singapore, 107-121.

[17] Dahri, M.K., Kooh, M.R.R., and Lim, L.B.L., 2014, Water remediation using low cost adsorbent walnut shell for removal of malachite green: Equilibrium, kinetics, thermodynamic and regeneration studies, J. Environ. Chem. Eng., 2 (3), 1434-1444.

[18] Robinson, T., McMullan, G., Marchant, R., and Nigam, P., 2001, Remediation of dyes in textile effluent: A critical review on current treatment technologies with a proposed alternative, Bioresour. Technol., 77 (3), 247-255.

[19] Dai, L., Zhu, W., He, L., Tan, F., Zhu, N., Zhou, Q., $\mathrm{He}, \mathrm{M}$., and $\mathrm{Hu}, \mathrm{G} ., 2018$, Calcium-rich biochar from crab shell: An unexpected super adsorbent for dye removal, Bioresour. Technol., 267, 510-516.

[20] Fil, BA, 2016, Isotherm, kinetic, and thermodynamic studies on the adsorption behavior of malachite green dye onto montmorillonite clay, Part. Sci. Technol., 34 (1), 118-126.

[21] Abdelrahman, E.A., 2018, Synthesis of zeolite nanostructures from waste aluminum cans for efficient removal of malachite green dye from aqueous media, J. Mol. Liq., 253, 72-82.

[22] Chen, Y., Lin, Y.C., Ho, S.H., Zhou, Y., and Ren, N., 2018, Highly efficient adsorption of dyes by biochar derived from pigments-extracted macroalgae pyrolyzed at different temperature, Bioresour. Technol., 259, 104-110. 
[23] Palapa, N.R., Juleanti, N., Mohadi, R., Taher, T., Rachmat, A., and Lesbani, A., 2020, Copper aluminum layered double hydroxide modified by biochar and its application as an adsorbent for procion red, J. Water Environ. Technol., 18 (6), 359-371.

[24] Blaisi, N.I., Zubair, M., Ihsanullah, I., Ali, S., Kazeem, T.S., Manzar, M.S., Al-Kutti, W., and Al Harthi, M.A., 2018, Date palm ash-MgAl-layered double hydroxide composite: Sustainable adsorbent for effective removal of methyl orange and eriochrome black-T from aqueous phase, Environ. Sci. Pollut. Res., 25 (34), 34319-34331.

[25] Chen, J., 2011, “Chapter 18 - Host-Guest Functional Materials" in Modern Inorganic Synthetic Chemistry, Eds. Xu. R., Pang, W., and Huo, Q., Elsevier, Amsterdam, 405-428.

[26] Shan, R., Yan, L., Yang, Y., Yang, K., Yu, S., Yu, H., Zhu, B., and Du, B., 2015, Highly efficient removal of three red dyes by adsorption onto $\mathrm{Mg}$-Al-layered double hydroxide, J. Ind. Eng. Chem., 21, 561-568.

[27] Zhu, Z., Ouyang, S., Li, P., Shan, L., Ma, R., and Zhang, P., 2020, Persistent organic pollutants removal via hierarchical flower-like layered double hydroxide: Adsorption behaviors and mechanism investigation, Appl. Clay Sci., 188, 105500.

[28] Starukh, H., and Levytska, S., 2019, The simultaneous anionic and cationic dyes removal with Zn-Al layered double hydroxides, Appl. Clay Sci., 180, 105183.

[29] Palapa, N.R., Juleanti, N., Normah, N., Taher, T., and Lesbani, A., 2020, Unique adsorption properties of malachite green on interlayer space of $\mathrm{Cu}-\mathrm{Al}$ and $\mathrm{Cu}-$ $\mathrm{Al}-\mathrm{SiW}_{12} \mathrm{O}_{40}$ layered double hydroxides, Bull. Chem. React. Eng. Catal., 15 (3), 653-661.

[30] Wang, T., Li, C., Wang, C., and Wang, H., 2018, Biochar/MnAl-LDH composites for $\mathrm{Cu}(\mathrm{II})$ removal from aqueous solution, Colloids Surf., A, 538, 443450.

[31] Lestari, N.A., 2019, Reduction of $\mathrm{CO}_{2}$ emission by integrated biomass gasification-solid oxide fuel cell combined with heat recovery and in-situ $\mathrm{CO}_{2}$ utilization, Evergreen, 6 (3), 254-261.
[32] Tareq, R., Akter, N., and Azam, M.S., 2019, "Chapter 10 - Biochars and Biochar Composites: Low-Cost Adsorbents for Environmental Remediationin" in Biochar from Biomass and Waste, Eds., Ok, Y.S., Tsang, D.C.W., Bolan, N., and Novak, J.M., Elsevier Inc., Amsterdam, Netherland, 169-209.

[33] Jerai, F., Miyazaki, T., Saha, B.B., and Koyama, S., 2015, Overview of adsorption cooling system based on activated carbon: Alcohol Pair, Evergreen, 2 (1), 30-40.

[34] Huang, D., Liu, C., Zhang, C., Deng, R., Wang, R., Xue, W., Luo, H., Zeng, G., Zhang, Q., and Guo, X., 2019, $\mathrm{Cr}$ (VI) removal from aqueous solution using biochar modified with $\mathrm{Mg} / \mathrm{Al}$-layered double hydroxide intercalated with ethylenediaminetetraacetic acid, Bioresour. Technol., 276, 127-132.

[35] Meili, L., Lins, P.V., Zanta, C.L.P.S., Soletti, J.I., Ribeiro, L.M.O., Dornelas, C.B., Silva, T.L., and Vieira, M.G.A., 2019, MgAl-LDH/biochar composites for methylene blue removal by adsorption, Appl. Clay Sci., 168, 11-20.

[36] Wan, S., Wang, S., Li, Y., and Gao, B., 2017, Functionalizing biochar with $\mathrm{Mg}-\mathrm{Al}$ and $\mathrm{Mg}-\mathrm{Fe}$ layered double hydroxides for removal of phosphate from aqueous solutions, J. Ind. Eng. Chem., 47, 246-253.

[37] Ravuru, S.S., Jana, A., and De, S., 2019, Synthesis of NiAl-layered double hydroxide with nitrate intercalation: Application in cyanide removal from steel industry effluent, J. Hazard. Mater., 373, 791800.

[38] Kajjumba, G.W., Emik, S., Öngen, A., Özcan, H.K., and Ayd, S., 2019, "Modelling of Adsorption Kinetic Processes-Errors, Theory and Application" in Modelling of Adsorption Kinetic Processes - Errors, Theory and Application, Eds. Edebali, S., IntechOpen, Rijeka, Croatia.

[39] Aljeboree, A.M., Alkaim, A.F., and Al-Dujaili, A.H., 2015, Adsorption isotherm, kinetic modeling and thermodynamics of crystal violet dye on coconut 
husk-based activated carbon, Desalin. Water Treat., 53 (13), 3656-3667.

[40] Shaji, A., and Zachariah, A.K., 2017, "Chapter 9 Surface Area Analysis of Nanomaterials" in Thermal and Rheological Measurement Techniques for Nanomaterials Characterization, Eds. Thomas, S., Thomas, R., Zachariah, A.K., and Mishra, R.K., Elsevier Inc., Amsterdam, Netherlands, 197-231.

[41] Parida, K.M., and Mohapatra, L., 2012, Carbonate intercalated $\mathrm{Zn} / \mathrm{Fe}$ layered double hydroxide: A novel photocatalyst for the enhanced photo degradation of azo dyes, Chem. Eng. J., 179 131-139.

[42] James, J., and Rao, M.S., 1986, Silica from rice husk through thermal decomposition, Thermochim. Acta, 97, 329-336.

[43] Mohapatra, S., Sakthivel, R., Roy, G.S., Varma, S., Singh, S.K., and Mishra, D.K., 2011, Synthesis of $\beta$ $\mathrm{SiC}$ powder from bamboo leaf in a DC extended thermal plasma reactor, Mater. Manuf. Processes, 26 (11), 1362-1368.

[44] Gholami, P., Khataee, A., Soltani, R.D.C., Dinpazhoh, L., and Bhatnagar, A., 2020, Photocatalytic degradation of gemifloxacin antibiotic using Zn-Co-LDH@biochar nanocomposite, J. Hazard. Mater., 382, 121070.

[45] Lesbani, A., Asri, F., Palapa, N.R., Taher, T., and Rachmat, A., 2020, Efficient removal of methylene blue by adsorption using composite based $\mathrm{Ca} / \mathrm{Al}$ layered double hydroxide-biochar, Global NEST J., 22 (2), 250-257.

[46] Harizi, I., Chebli, D., Bouguettoucha, A., Rohani, S., and Amrane, A., 2019, A new Mg-Al-Cu-Fe-LDH composite to enhance the adsorption of acid red 66 dye: characterization, kinetics and isotherm analysis, Arabian J. Sci. Eng., 44 (6), 5245-5261.

[47] Abukhadra, M.R., Sayed, M.A., Rabie, A.M., and Ahmed, S.A., 2019, Surface decoration of diatomite by $\mathrm{Ni} / \mathrm{NiO}$ nanoparticles as hybrid composite of enhanced adsorption properties for malachite green dye and hexavalent chromium, Colloids Surf., A, 577, 583-593.

[48] Bagheri, R., Ghaedi, M., Asfaram, A., Alipanahpour Dil, E., and Javadian, H., 2019, RSM-CCD design of malachite green adsorption onto activated carbon with multimodal pore size distribution prepared from Amygdalus scoparia: Kinetic and isotherm studies, Polyhedron, 171, 464-472.

[49] Jiang, F., Dinh, D.M., and Hsieh, Y.L., 2017, Adsorption and desorption of cationic malachite green dye on cellulose nanofibril aerogels, Carbohydr. Polym., 173, 286-294.

[50] Rajabi, M., Mahanpoor, K., and Moradi, O., 2019, Preparation of PMMA/GO and PMMA/GO- $\mathrm{Fe}_{3} \mathrm{O}_{4}$ nanocomposites for malachite green dye adsorption: Kinetic and thermodynamic studies, Composites, Part B, 167, 544-555.

[51] Raghu, M.S., Kumar, K.Y., Prashanth, M.K., Prasanna, B.P., Vinuth, R., and Pradeep Kumar, C.B., 2017, Adsorption and antimicrobial studies of chemically bonded magnetic graphene oxide$\mathrm{Fe} 3 \mathrm{O} 4$ nanocomposite for water purification, $J$. Water Process Eng., 17, 22-31.

[52] Palapa, N.R., Taher, T., Wijaya, A., and Lesbani, A., 2021, Modification of $\mathrm{Cu} / \mathrm{Cr}$ layered double hydroxide by Keggin type polyoxometalate as adsorbent of malachite green from aqueous solution, Sci. Technol. Indones., 6 (3), 209-217.

[53] Zhang, J., Liu, M., Yang, T., Yang, K., and Wang, H., 2016, A novel magnetic biochar from sewage sludge: Synthesis and its application for the removal of malachite green from wastewater, Water Sci. Technol., 74 (8), 1971-1979.

[54] Sharifpour, E., Alipanahpour Dil, E., Asfaram, A., Ghaedi, M., and Goudarzi, A., 2019, Optimizing adsorptive removal of malachite green and methyl orange dyes from simulated wastewater by $\mathrm{Mn}$ doped CuO-nanoparticles loaded on activated carbon using CCD-RSM: Mechanism, regeneration, isotherm, kinetic, and thermodynamic studies, Appl. Organomet. Chem., 33 (3), e4768.

[55] Normah, N., Palapa, N.R., Taher, T., Mohadi, R., Utami, H.P., and Lesbani, A., 2021, The ability of composite $\mathrm{Ni} / \mathrm{Al}$-carbon based material toward readsorption of iron(II) in aqueous solution, Sci. Technol. Indones., 6 (3), 156-165. 
[56] Naushad, M., Alqadami, A.A., AlOthman, Z.A., Alsohaimi, I.H., Algamdi, M.S., and Aldawsari, A.M., 2019, Adsorption kinetics, isotherm and reusability studies for the removal of cationic dye from aqueous medium using arginine modified activated carbon, $J$. Mol. Liq., 293, 111442.
[57] Nishimura, S., Takagaki, A., and Ebitani, K., 2010, Monodisperse iron oxide nanoparticles embedded in $\mathrm{Mg}$-Al hydrotalcite as a highly active, magnetically separable, and recyclable solid base catalyst, Bull. Chem. Soc. Jpn., 83 (7), 846-851. 